\title{
Mislingar - á hverfanda hveli?
}

\section{Sigurður Guðrmundsson}

fyrrum landlæknir, sérfræðingur í lyflækningum og smitsjúkdómum, lyflækningasviði Landspítala, prófessor, læknadeild Háskóla Íslands

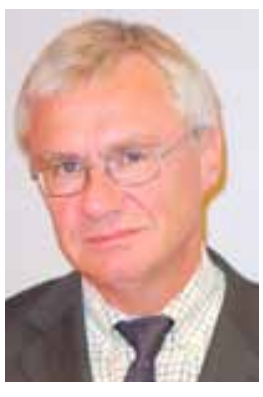

siggudm@landspitali.is

Mislingar hafa vafalítið fylgt mannkyni frá örófi alda. Peim var einna fyrst lýst á 9. öld af lækni í hinni fornu Persíu sem greindi á milli bólusóttar og mislinga. Sjúkdómurinn olli miklum búsifjum í fyrri tíð, og dæmi eru um að byggðarlög hafi nærfellt lagst í auðn af hans völdum. Hann er talinn hafa lagt um 200 milljónir manna að velli síðastliðin 150 ár og enn deyja um 150-160 púsund börn árlega prátt fyrir að bóluefni hafi verið til reiðu frá miðjum sjöunda áratug síðustu aldar. ${ }^{1}$

Í pví ljósi eru niðurstöður Söndru Gunnarsdóttur og fleiri² sem birtast í pessu tölublaði Læknablaðsins sérlega áhugaverðar. Pau lýsa par áhrifum og afleiðingum tveggja faraldra mislinga sem bárust til hins einangraða samfélags á Íslandi á 19. öld. Gerla er sýnt fram á áhrif mjög smitandi alvarlegs sjúkdóms í mjög næmu pýði, hraða útbreiðslu, mikilvægi hjarðónæmis, fjór- til fimmfalda aukningu dauðsfalla, áhrif á konur á fæðingaraldri og mikla lækkun fæðingartíðni. Áhrifamikil lexía. Ekki er greinin síður áhugaverð vegna aðferðanna sem beitt var til að afla gagna. Bar par hæst kirkjubækur sem prestar skráðu af mikilli natni; sýnir að stöku sinnum fara trú og vísindi saman.

Hvað hefur breyst frá pessum tímum? Mislingar eru sjúkdómur sem er unnt að útrýma, rétt eins og bólusótt 1977, veiran leggst eingöngu á menn, ekkert „forðabúr" er í umhverfi eða meðal dýra, bóluefni er mjög virkt og öruggt. Ekki hefur petta pó tekist enn. Ýmislegt hefur pó áunnist. Dauðsföllum fækkaði á heimsvísu um 70\% frá 2000 til 2011 og ætluð pekjun fyrsta skammts bóluefnis jókst úr 72\% í 84\% á sama tíma. ${ }^{1}$ Mislingum var "útrýmt" í Vesturálfu árið 2002, pannig að tilfelli sem greinast par nú eru öll innflutt. Um tíma var útlit í Afríkulöndum líka gott, skráð heildarnýgengi mislinga 2008 var minna en $10 \%$ nýgengis ársins $2000 .^{3}$

Hins vegar hefur verr gengið annars staðar. Alpjóðaheilbrigðismálastofnunin metur pað svo að um 20 milljónir barna hafi ekki fengið fyrsta skammt af bóluefni árið 2011. Um helmingur peirra býr í 5 löndum: Kongó, Epíópíu, Indlandi, Nígeríu og Pakistan. ${ }^{1}$ Ástæða pessa er flestum kunn, fátækt, skortur á aðgengi að heilbrigðispjónustu, og skortur á pekkingu og menntun. Parna er enn verk að vinna sem fyrr.

Hins vegar er annað upp á teningnum í ýmsum löndum sem standa okkur nær. Par hefur mönnum skriplað á skötu, ekki síst eftir árið 2005, og illa gengið að halda viðunandi pekjun mislingabólusetninga. Má par einkum nefna Bretland, Írland, Sviss, Ítalíu, Pýskaland, Frakkland og Rúmeníu, en í pessum löndum er nýgengi mislinga enn allt of hátt. Árin 2010 og 2011 greindust um 30.000 tilvik mislinga árlega í Evrópu, en mun færri 2012 og 1013, eða 8-10 púsund. Um mitt ár 2013 hófst svo faraldur í Hollandi. ${ }^{1}$

Á pessum slóðum er ástæðan síður fátækt, skortur á menntun eða ónógt aðgengi að upplýsingum, heldur fremur gagnrýnislaus ofurtrú á rangar upplýsingar, sem sumar urðu til vegna pess að rangt var haft við í vísindarannsóknum. Sumt má rekja til misskilinna tilvísana í meinta skoðun almættisins. Vissulega á vísindasamfélagið einnig sinn hlut að pessu máli, en árið 1998 birti eitt virtasta læknisfræðitímarit veraldar, Lancet, sællar minningar, svikagrein Wakefields og fleiri ${ }^{4}$ um tengsl bólusetninga gegn mislingum, rauðum hundum og hettusótt við einhverfu. Hún var dregin til baka 6 árum síðar, en skaðinn sem af pessu hefur hlotist er hins vegar ómældur.

Sigið hefur á ógæfuhlið víðar. Í Afríku fjölgaði tilfellum 4-5-falt frá 2008 til 2010, ${ }^{3}$ bæði hjá eldri unglingum og fullorðnum, en einnig og ekki síður hjá mjög ungum börnum, jafnvel á fyrsta ári. Vaxandi umræða er um að hefja bólusetningu fyrr af pessum völdum. Meðal annars hefur verið sýnt fram á virkni bóluefnis hjá fjögurra mánaða börnum. ${ }^{5}$

Við hér í fásinninu vorum ópyrmilega minnt á pessa nálægð við mislinga nýverið, en hér greindist barn með mislinga á barnaspítala Hringsins. •að var ungt og pví ekki bólusett, en hafði heimsótt landsvæði par sem faraldur geisar. Ekki hafa greinst fleiri tilfelli sem betur fer, en pau börn sem útsett voru fyrir smiti voru vel rúmt stórt hundrað.

Parna sluppum við með skrekkinn, en tímaspursmál er hvenær eitthvað pessu líkt gerist næst meðan vörnum á heimsvísu er ekki betur fyrir komið en raun ber vitni. Fræðilega er unnt að útrýma mislingum og að pví er róið öllum árum. Að einhverju leyti eru peir á hverfanda hveli, en enn virðist útrýming ekki í augsýn. Við purfum að gera mun betur.

\section{Heimildir}

1. www.who.int - mars 2014.

2. Gunnarsdóttir S, Briem H, Gottfreðsson M. Umfang og áhrif mislingafaraldranna 1846 og 1882 á Íslandi. Læknablaðið 2014; 100: 211-6.

3. Mulholland EK, Griffiths UK, Biellik R. Measles in the 21st Century. N Engl J Med 2012; 366: 1755-6.

4. Wakefield AJ, Murch SH, Anthony A, Linnell J, Casson DM, Malik M, et al. Ileal-lymphoid-nodular hyperplasia, non-specific colitis, and pervasive developmental disorder in children. Lancet 1998; 351: 637-41. doi:10.1016/S01406736(97)11096-0. (Retracted).

5. Martins CL, Garly M-L, Balé C, Rodrigues A, Ravn $\mathrm{H}$, Whittle $\mathrm{HC}$, et al. Protective efficacy of standard Edmonston-Zagreb measles vaccination in infants aged 4.5 months: intanalysis of a randomized clinical trial. BMJ 2008; 337: a661.

Measles, not eradicated yet

Sigurdur Gudmundsson MD, PhD Consultant in Internal Medicine and Infectious Diseses, Landspitali University Hospital Professor, School of Medicine, University of Iceland 